\title{
EVALUATION OF DEEP ECOLOGY THOUGHT IN KONYA CLOSED BASIN
}

\author{
Sukru Dursun ${ }^{1}$ \\ ${ }^{1 *}$ Konya Technical University, Engineering and Natural Science Faculty, Environmental Engineering \\ Department, Konya, Turkey; \\ "Corresponding Author Sukru Dursun, e-mail: sdursun@ktun.edu.tr;
}

Received November 2020; Accepted December 2020; Published March 2021;

DOI: https://doi.org/10.31407/ijees11.201

\begin{abstract}
Social ecology suggests that the idea of dominating nature does not stem from the domination of other people, not the contrary. Obviously, it is the result of the effects of the ecological depression and is mainly of a sociological nature. The historical emergence of states, classes, hierarchies, and the resulting market capitalism and economy, are the social forces that cause the present degradation of the biosphere, both ideologically and materially. Value judgments in society are constantly changing. However, the concept of value, which is one of the basic elements of ecology, reveals the deep ecology. The sociology of deep ecology has two important principles that explain the concepts of value: The good condition and development of human and non-human life on the earth does not happen by itself, and these values should be independent of whether the world outside of man is beneficial for human interests. The quality and quantity of life forms on the globe contribute to the emergence of these values and is an important value for him. Since the end of the last two centuries, the idea of sustainable development has been accepted as a guiding rule for economic development and environmental policies. The definition of acceptable sustainable development has received a number of criticisms, including the failure to recognize dynamic humanenvironment relationships, with its strong emphasis on meeting people's needs due to economic developments. In response to these shortcomings, the concepts of resilience and adaptive governance emerged as alternative perspectives for sustaining sustainable development. It is the most important situation that the environment cannot give the desired response to these changes and the changes that occur continue unlimitedly, as people change their environment in a way that can be associated with the world in general in the direction of their own interests. In this context, in this study, the term deep ecology is considered to be evaluated in Konya Closed Basin. The point emphasized in the study is that besides the importance of the idea of deep ecology, urgent and rapid studies on this subject are very important.
\end{abstract}

Keywords: Social Ecology, Deep Ecology, Konya Closed Basin, Ecology Thinking 